
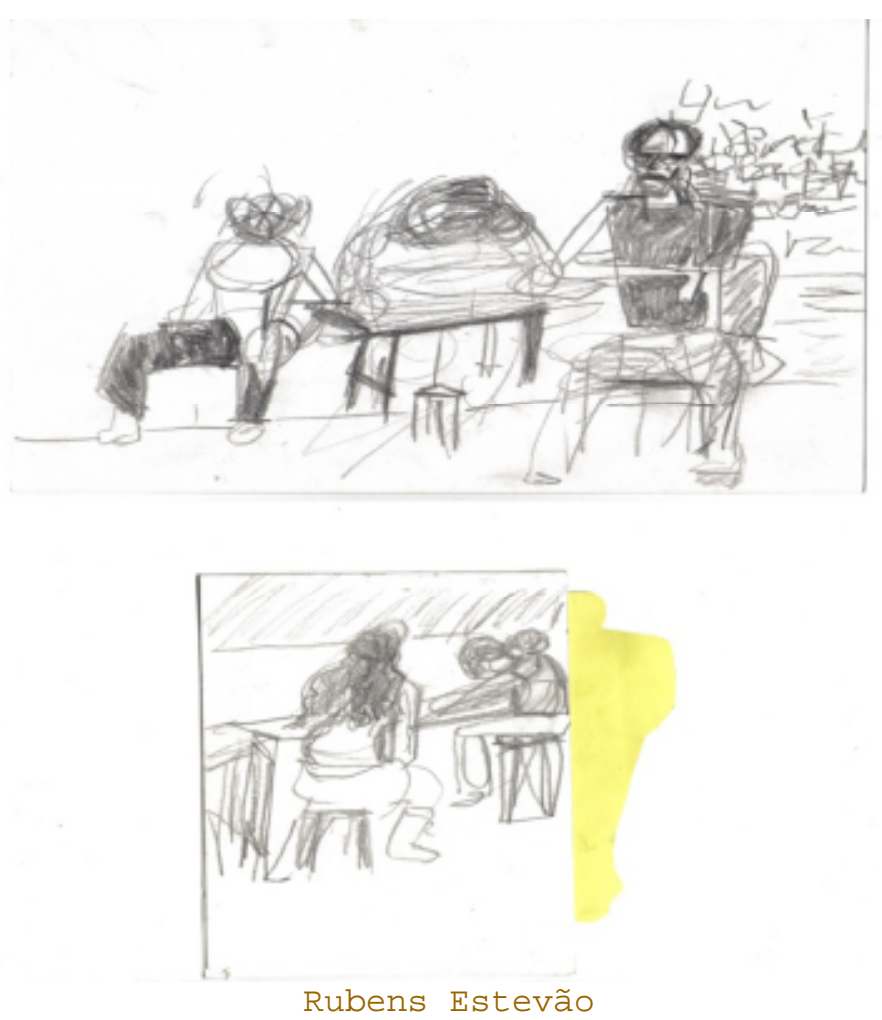

\title{
A invasão
}

\section{Renato Giovani de Souza Pereira}

Renato Giovani Pereira é graduado em Letras pela Universidade Federal do Rio Grande do Sul. Mestrando em Literatura Comparada. Professor de Língua Portuguesa e Espanhola. Atua no Instituto Cultural Cervantes, Porto Alegre. Escreve contos e novelas.

y al mirar la doble callejuela multiforme por el vidrio de la ventana, me di cuenta que el otro, el hombre de dos caras, me veía también a mi

Sempre que fecho os olhos. Agora tenho medo até. Ainda se eu pudesse não sentir, não ver, e se houvesse maneira de eu acreditar que tudo não passa de sonho, fantasia apenas, loucura, mas. Ele é quem decide as coisas por aqui, é ele quem brinca comigo me olhando com aquele olhar cretino, aquele 
olhar apertado que me lembra um risinho de deboche. Ele tem o poder agora (e como gosta de ser poderoso!). E mesmo com os olhos abertos eu posso senti-lo, posso ouvir as bobagens que ele diz usando a minha boca e a minha língua, sorrindo com os meus dentes. E observo o quanto gesticula, jogando meus braços de um lado para o outro, como se eu fosse um boneco de pano. Eu posso ver e sentir tudo isso o tempo todo, mas aquele olhar de riso debochado que tanto me tortura e que me machuca só de pensar, e que me deixa assim querendo que eu não fosse tão pequeno e não chorasse por dentro tanto, aquele olhar é só quando fecho os olhos.

Tudo (desta vez, a única de que tenho plena consciência) começou por volta de quatorze semanas atrás. Lembro que foi numa tarde clara de um dia muito quente que comecei a perceber que ele me habitava. Não sei dizer há quanto tempo morava em mim, mas é possível que sempre tivesse vivido ali, escondido em meu frágil e pequeno corpo desde a mais tenra infância. 0 que importa mesmo é que (agora) foi nessa tarde, justo nessa tarde quente, que ele começou a manifestar sua terrível arrogância. Numa tarde clara. É verdade que os últimos tempos têm-se mostrado um tanto turvos, mas quatorze semanas atrás ainda havia certa claridade. Porque foi numa tarde bastante clara.

Não falava comigo no começo; apenas respondia aos outros, por mim, coisas que eu não ousaria responder, respostas que por muitas vezes se mostravam contrárias ao meu próprio pensamento.

Estava sempre ali, e às vezes (como num espelho) eu podia vêlo, sempre que eu fechasse os olhos. Como num espelho porque, embora ele usasse roupas um tanto quanto extravagantes e tivesse um corte de cabelo nada discreto, com pontas compridas alouradas e uma franja muito azul, num colorido que nunca me fora próprio, parecia-se comigo na aparência. E aquela franja azul me lembrava sempre o mar, porque quando eu ficava de olhos fechados olhando para ela eu via a imagem de uma onda muito azul, batendo nas pedras e voltando, e batendo, e voltando, e batendo de novo, calma e sempre a mesma água, sempre uma onda muito azul, porém como se fosse outra.

Parecia-se comigo por trás da máscara. Em verdade, ainda se parece (tenho falado disso tudo no passado porque ele, agora, já não é mais ele, embora ainda esteja aqui).

Aos poucos fui tentando manter com ele uma espécie de diálogo, eu tentava comunicar-me, perguntava coisas (Por que estava ali? O que queria? Por que me fazia sofrer tanto? E por que eu sentia aquela vontade de chorar o dia inteiro até que meus olhos secassem, enquanto ele, debochado e arrogante, ria 
sempre?). Mas ignorava-me por completo. Só pensava em arrotar bobagens sem sentido, em distribuir aos outros suas opiniões estapafúrdias. E o que me dava mais nojo, a ponto de fazer-me vomitar às vezes, era o fato de ele usar a minha boca para falar aquelas asneiras todas; aquele lixo passava pela minha própria língua, deixando-a pegajosa e gosmenta de tanta imundície. E usava minha boca como se fosse mesmo sua, o que fazia com que eu parecesse, para os outros, diverso do que realmente era. Não sabiam que ele, aprisionado em mim, faziame de escravo, e que seu descaso não me dava chances de liberdade, e sequer podia eu entendê-lo.

De todos na casa, apenas o Narciso soube dele. Os outros só pensavam em dizer que eu estava culpado. Que eu era o responsável por toda aquela estranheza dentro de mim, por tudo de errado que ele fiz sem que eu quisesse, por todas as coisas que eu falou sem ter vontade. E a casa, embora estivesse cada vez mais cheia, continuava vazia para nós. E cada um (pai, mãe, irmão, tio, avô, e até mesmo a irmã que sempre parecera imune a qualquer doença) se escondia, se apertava no seu canto, e os quartos da casa continuavam sendo os lugares mais habitados. Não fosse essa distância talvez até soubessem dele, e pudessem me ajudar, e até fizessem com que ele não me doesse tanto assim.

Mas o Narciso, ah! O Narciso sim é que sabia de tudo. Apenas ele, com aquela transparência de vidro que sempre carregou nos olhos, deixava entrever que conhecia a minha desgraça. Estava consciente, eu sabia, apesar de haver tentado dissimular, como sempre fazia com tudo. Um dissimulado, o Narciso. Mas aqueles grandes olhos transparentes me faziam sentir que ele havia testemunhado tudo: desde o momento em que eu fora invadido até - começo da dominação. E Narciso andava quieto, cabisbaixo (há tempos não me pedia um carinho), mas passava horas a observarme, dizendo-me, com os olhos e com aquele meio sorriso felino, que sabia.

E no meio de um delírio tive uma visão que me encheu o peito de esperança: lá em casa, todos nós agora tínhamos cabeças de gato, felpudas, macias, e nossos olhos se enchiam de transparência e vida. E logo me veio a figura de Narciso, e pensei o quanto ele era carinhoso e nunca tinha medo de pedir e dar carinho aos outros, embora por vezes até pudesse arranhar ou morder alguém. E então tive aquela idéia que me encheu de alegria: meio gatos, meio homens, agora poderíamos ser um pouco mais dissimulados, e, fingindo sentir aquilo que sentimos e que tanto nos machuca, encostar-nos uns aos outros pedindo um afago, como fazem os gatos, como o Narciso sempre fez. Assim, poderíamos fingir que 0 amor que sentimos uns pelos outros não nos dói tanto assim, e poderíamos até dissimular que todo esse amor nunca existiu, e que nós, agora 
gatos, só queremos que as nossas mãos acariciem nosso pêlo macio, só por um instante.

Tanta gente naquela casa e o gato era o único que sabia. A criatura dentro de mim crescendo, e aumentando mais ainda o sorriso debochado daquele olhar. Quanto mais ele me persegue, quanto mais ele me castiga com seus golpes sujos, mais eu me apego ao gato, como se ele pudesse me salvar. Mas o Narciso tem andado meio afastado, já não me observa tanto.

E agora, no momento em que descubro que Narciso se afastou de mim por medo, tudo começa a desmoronar, porque conheço 0 Narciso como ninguém e sei que de mim ele jamais teria medo. Jamais!

E habitando aquele corpo fui crescendo... Este sorriso debochado nos meus olhos o gato já deve ter notado, o mesmo sorriso que o outro também via dentro dele, sempre que fechasse os olhos. 